\title{
The State-of-the-Art of Hydrography in Europe and North America
}

\author{
Cesar C. Pimenta, Intelligent Maritime Solutions Consultoria Ltda
}

Copyright 2021, SBGf - Sociedade Brasileira de Geofísica.

This paper was prepared for presentation during the $17^{\text {th }}$ International Congress of the Brazilian Geophysical Society held in Rio de Janeiro, Brazil, 8-11 November 2021.

Contents of this paper were reviewed by the Technical Committee of the $17^{\text {th }}$ International Congress of the Brazilian Geophysical Society and do not necessarily represent any position of the SBGf, its officers or members. Electronic reproduction or storage of any part of this paper for commercial purposes without the written consent of the Brazilian Geophysical Society is prohibited.

\begin{abstract}
The purpose of this presentation is to disseminate European and North American initiatives that add the concepts of "timeliness" and "efficiency" to the definition of Hydrography by the International Hydrographic Organization. According to the Merriam-Webster English Dictionary (online version), state-of-the-art is "the level of development (as of a device, procedure, process, technique, or science) reached at any particular time, usually as a result of modern methods." Cambridge English Dictionary (online version) defines timeliness as "the fact or quality of happening at best possible time or at the right time" and associates efficiency with results obtained with the optimized use of available resources. Ports, the oil and gas industry, coastal management, response to extreme weather events, and defense demand responses from the Hydrography at speed often incompatible with the traditional process. Moreover, we live in a time of paradigm shift, when the S-100 and eNavigation redefine the concept of the state-of-the-art in Hydrography. We will see, throughout the presentation, among other things, how the Port of Rotterdam goes from the acquisition of the bathymetry to the updating of the electronic chart in less than a day; how uncrewed vessels are changing the concepts of data acquisition; how NOAA interacts with industry to accelerate the adoption of various products under the S-100; and we will end up looking at new sensors and new practices.
\end{abstract}

